\title{
Perbedaan Pemahaman Konsep Ikrar Talak Menurut Putusan Pengadilan Agama dengan Syariat Islam
}

\author{
Nourma Dewi ${ }^{1}$, Femmy Silaswaty ${ }^{2}$ \\ Fakultas Hukum Universitas Islam Batik Surakarta \\ Email: Nourma_hukum92@yahoo.co.id,femmysilaswaty@gmail.com
}

\begin{abstract}
Abstrak. Penelitian ini bertujuan untuk mengetahui perbedaan pemahaman konsep ikrar talak menurut putusan pengadilan agama dengan syariat islam. Penelitian ini merupakan penelitian hukum normatif. Pendekatan penelitian yang digunakan dalam penelitian ini adalah pendekatan perundang-undangan dan pendekatan konseptual. Berdasarkan hasil penelitian dan pembahasan dapat disimpulkan bahwa terdapat ketidaksinkroran konsep antara pengadilan agama yang berpegang pada Kompilasi hukum Islam dengan syariat islam meliputi jatuhnya talak, upaya hukum, dan berlakunya masa iddah.
\end{abstract}

Kata kunci : ikrar, talak, pengadilan agama

Abstract. This study aims to determine the differences in understanding the concept of talaq pledges according to the decisions of religious courts with Islamic Shari'a. This research is normative legal research. The research approach used in this study is the legislative approach and the conceptual approach. Based on the results of the research and discussion it can be concluded that there is a concept inconsistency between the religious courts that adhere to the Compilation of Islamic law with Islamic Shari'a which includes the fall of divorce, legal remedies, and the enactment of the Islamic period.

Keywords: pledge, divorce, religious court

\section{PENDAHULUAN}

Berdasarkan Pasal 1 Undang - Undang Nomor 1 Tahun 1974 Tentang Perkawinan (selanjutnya disebut UUP), Perkawinan adalah ikatan lahir dan batin antara seorang pria dengan seorang wanita sebagai suami istri dengan tujuan membentuk keluarga (rumah tangga) yang bahagia dan kekal berdasarkan Ketuhanan Yang Maha Esa. Sedangkan menurut Pasal 2 Kompilasi Hukum Islam (KHI), perkawinan adalah akad yang sangat kuat (mistaqan ghalidan) untuk mentaati perintah Allah dan melaksanakannya merupakan ibadah.

Pengertian perkawinan di atas menunjukkan bahwa perkawinan dilaksanakan dengan niatan bahwa akan kekal seumur hidup. Jika pernikahan dilaksanakan dengan menaati perintah Allah dan melaksanakannya sesuai syariat agama, diharapkan pasangan suami tersebut mampu membentuk keluarga yang sakinah, mawaddah, dan rahmah

Terkait dengan istilah sakinah, mawaddah dan rahmah, memunculkan beragama definisi. Di antaranya adalah Al-Isfahan (ahli fiqh dan tafsir) mengartikan sakînah dengan tidak adanya rasa gentar dalam menghadapi sesuatu; Menurut al-Jurjani (ahli bahasa), sakînah adalah adanya ketentraman dalam hati pada saat datangnya sesuatu yang tidak diduga, dibarengi satu nûr (cahaya) dalam hati yang memberi ketenangan dan ketentraman pada yang menyaksikannya, dan merupakan keyakinan berdasarkan penglihatan (ain al yaqîn). Ada pula yang menyamakan sakînah itu dengan kata rahmah dan thuma 'nî nah, artinya tenang, tidak gundah dalam melaksanakan ibadah. ${ }^{3}$

Pada pelaksanaannya, perkawinan tidak berlangsung dengan baik sehingga terjadilan putusnya perkawinan yang biasa disebut dengan perceraian. Putusnya ikatan perkawinan dapat disebabkan karena berbagai hal seperti perceraian (Pasal $114 \mathrm{KHI}$ ), talak atau karena gugatan perceraian. Talak adalah melepaskan (memutuskan) ikatan pernikahan dengan lafadz yang jelas, seperti :kamu saya cerai", atau dengan lafadz kiasan dengan disertai niat, seperti "pulanglah kamu kepada keluargamu" sedangkan menurut Pasal 117 KHI, talak adalah ikrar suami di hadapan sidang Pengadilan Agama. Talak tersebut menurut Pasal

\footnotetext{
${ }^{1}$ Fakultas Hukum Universitas Islam Batik Surakarta

${ }^{2}$ Fakultas Hukum Universitas Islam Batik Surakarta

${ }^{3}$ Ismatulloh, A.M. 2015. Konsep Sakinah, Mawaddah dan Rahmah dalam Al-Qur'an (Prespektif Penafsiran Kitab Al Qur'an dan Tafsirnya),Jurnal Mazahib. Vol. XIV. No. 1, Hal. 53-63, hal. 54.
} 
129 KHI dilakukan oleh si suami dengan mengajukan permohonan baik lisan maupun tertulis kepada Pengadilan Agama yang mewilayahi tempat tinggal isteri disertai dengan alasan serta meminta agar diadakan sidang untuk keperluan penjatuhan ikrar talak tersebut . Di dalam praktik, permohonan yang diajukan oleh suami tersebut dikenal dengan sebutan permohonan talak, yang mana suami berkedudukan sebagai Pemohon, sedangkan istri sebagai Termohon.

Berdasarkan Pasal $115 \mathrm{KHI}$, perceraian hanya dapat dilakukan di depan sidang Pengadilan Agama setelah Pengadilan Agama tersebut berusaha dan tidak berhasil mendamaikan kedua belah pihak (suamiistri). Disamping itu, perceraian dapat terjadi karena alasan - alasan berikut:

1. Salah satu pihak berbuat zina atau menjadi pemabuk, pemadat, penjudi, dan lain sebagainya yang sukar disembuhkan; Salah satu pihak berbuat zina atau menjadi pemabuk, pemadat, penjudi dan lain sebagainya yang sukar disembuhkan (Pasal 116 KHI dan Pasal 19 PP No. 9 Tahun 1975);

2. Salah satu pihak meninggalkan pihak lain selama 2 (dua) tahun berturut-turut tanpa izin pihak lain dan tanpa alasan yang sah atau karena hal lain diluar kemampuannya disembuhkan (Pasal $116 \mathrm{KHI}$ dan Pasal 19 PP No. 9 Tahun 1975);

3. Salah satu pihak mendapat hukuman penjara 5 (lima) tahun atau hukuman yang lebih berat setelah perkawinan berlangsung disembuhkan (Pasal 116 KHI dan Pasal 19 PP No. 9 Tahun 1975);

4. Salah satu pihak melakukan kekejaman atau penganiayaan berat yang membahayakan pihak lain disembuhkan (Pasal 116 KHI dan Pasal 19 PP No. 9 Tahun 1975);

5. Salah satu pihak mendapat cacat badan atau penyakit dengan akibat tidak dapat menjalankan kewajibannya sebagai suami atau isteri disembuhkan (Pasal 116 KHI dan Pasal 19 PP No. 9 Tahun 1975);

6. Antara suami dan isteri terus menerus terjadi perselisihan dan pertengkaran dan tidak ada harapan akan hidup rukun lagi dalam rumah tangga disembuhkan (Pasal 116 KHI dan Pasal 19 PP No. 9 Tahun 1975);

7. Suami melanggar taklik talak (Pasal $116 \mathrm{KHI}$ )

8. Peralihan agama atau murtad yang menyebabkan terjadinya ketidak rukunan dalam rumah tangga (Pasal $116 \mathrm{KHI})$.

Berdasarkan ketentuan di atas, maka perceraian itu sah apabila dilakukan di depan sidang Pengadilan Agama (setelah Pengadilan Agama tersebut berusaha dan tidak berhasil mendamaikan suami-istri) dan disertai dengan alasan-alasan perceraian sebagaimana diatur dalam Pasal 116 KHI. Lebih lanjut, perceraian terhitung sejak jatuhnya putusan Pengadilan Agama yang telah mempunyai kekuatan hukum yang tetap/inkracht van gewijsde (Pasal 146 ayat )2) KHI) beserta akibat-akibatnya. Khusus bagi perceraian karena talak, perceraian tersebut terjadi setelah suami mengucapkan ikrar talak di depan sidang Pengadilan Agama.

Secara hukum, ikrar talak memang harus dilakukan di depan pengadilan. Akan tetapi, sebelum adanya proses di pengadilan, terkadang suami telah melakukan ikrar talak di luar pengadilan. Bahkan tidak jarang terdapat kasus suami mengucapkan ikrar talak tiga. Pemahaman tersebut sangat berbeda dengan yang terjadi di proses peradilan, dimana walaupun di luar pengadilan suami mengucapkan ikrar talak tiga, secara hukum tetap dianggap talak satu. Hal tersebut tentunya menimbulkan penafsiran dan akibat hukum yang berbeda dari putusan pengadilan dengan aturan syariat islam.

Berdasarkan latar belakang di atas maka dapat diambil rumusan masalah sebagai berikut: Bagaimana perbedaan pemahaman konsep ikrar talaq menurut putusan Pengadilan Agama dengan syariat Islam?

\section{METODE PENELITIAN}

Penelitian ini menggunakan metode penelitian hukum normatif, Dalam penelitian ini dipergunakan pendekatan perundang-undangan (Statute Approach) dan pendekatan kasus (case approach). Pendekatan perundang-undangan dilakukan untuk meneliti aturan perundang-undangan dan peraturan sesuai syariat islam yaitu Al-Qur'an, Hadist, dan Fiqih.

HASIL DAN PEMBAHASAN

Konsep Ikrar Talak Menurut Pengadilan Agama (Kompilasi Hukum Islam dan Undang-Undang Perkawinan) 
Perceraian merupakan alternatif terakhir yang boleh ditempuh manakala bahtera kehidupan rumah tangga tidak dapat lagi dipertahankan keutuhan dan kesinambungannya. Sifatnya sebagai alternatif terakhir, Islam menunjukkan agar sebelum terjadinya perceraian, ditempuh usaha-usaha perdamaian antara kedua belah pihak, karena ikatan perkawinan adalah ikatan yang paling suci dan kokoh. Perceraian hukumnya bisa menjadi wajib jika mudharat yang menimpa salah satu pasangan suami istri itu tidak dapat dihilangkan kecuali dengan perceraian. Perceraian juga hukumnya bisa menjadi haram apabila menimbulkan mudharat bagi salah satu pasangan suami istri dan tidak dapat menghilangkan mudharat tersebut atau menyamainya. ${ }^{4}$ Perceraian dalam hukum negara diatur dalam:

a. Bab VIII Tentang Putusnya Perkawinan serta akibatnya Pasal 38-Pasal 41 Undang-Undang No. 1 tahun 1974 tentang;

b. Bab V Tentang Tata Cara Perceraian Pasal 14-Pasal 36 Peraturan Pemerintah No. 9 tahun 1975 tentang Pelaksanaan Undang-Undang Perkawinan;

c. Pasal 65-Pasal 91 Undang-Undang No. 7 tahun 1989 tentang Peradilan Agama menjelaskan tentang tata cara pemeriksaan sengketa perkawinan;

d. Pasal 114-Pasal 148 Bab XVI tentang Putusnya Perkawinan dan Pasal 149-Pasal 162 Bab XVII tentang Akibat Putusnya Perkawinan Instruksi Presiden No. I tahun 1991 tentang Kompilasi Hukum Islam.

Perkawinan menurut Pasal 2 ayat (1) UUP, sah apabila dilakukan menurut hukum masing-masing agama dan kepercayaannya. Dalam pengertian, perkawinan adalah sah apabila telah dilaksanakan menurut rukun dan syarat-syarat yang ditentukan oleh masing-masing agama dan kepercayaannya tersebut. Sedangkan, pencatatan perkawinan di Kantor Urusan Agama bertujuan untuk memberikan kepastian hukum terhadap peristiwa perkawinan yang terjadibeserta akibat-akibatnya.

Pasal 38 UUP, Perkawinan dapat putus karena :

a. Kematian

b. Perceraian

c. Atas Keputusan pengadilan.

\section{Pasal 39 UUP :}

Ayat (1) Perceraian hanya dapat dilakukan di depan sidang pengadilan setelah pengadilan yang bersangkutan berusaha dan tidak berhasil mendamaikan kedua belah pihak.

Ayat (2) Untuk melakukan perceraian harus ada cukup alasan, bahwa antara suami isteri itu tidak akan dapat hidup rukun sebagai suami isteri.

Ayat (3) Tata cara perceraian di depan pengadilan diatur dalam perundang-undangan tersendiri.

Pasal 113 KHI sama dengan Pasal 38 UUP. Pasal 114 KHI berbunyi “ putusnya perkawinan yang disebabkan karena perceraian dapat terjadi karena talak atau berdasarkan gugatan perceraian”. Pasal 115 KHI menegaskan " perceraian hanya dapat dilakukan di depan sidang pengadilan agama setelah pengadilan agama tersebut berusaha dan tidak berhasil mendamaikan kedua belah pihak".

Mengenai alasan-alasan terjadinya perceraian dijelaskan dalam Pasal 19 PP No. 9 Tahun 1975 jo. Pasal 116 KHI.

Di dalam hukum yang berlaku di Indonesia yang mengatur tentang perkawinan, tidak diatur dan tidak dikenal pengertian talak di bawah tangan. Pengertian talak menurut Pasal 117 KHI adalah ikrar suami di hadapan sidang Pengadilan Agama yang menjadi salah satu sebab putusnya perkawinan Pasal 117 KHI menyatakan : "talak adalah ikrar suami di hadapan sidang Pengadilan Agama yang menjadi salah satu sebab putusnya perkawinan, dengan cara sebagaimana dimaksud dalam Pasal 129, 130, dan 131.

\section{Talak menurut Syariat Islam}

Talak ialah terurainya ikatan nikah dengan perkataan yang jelas, misalnya suami berkata kepada isterinya, "engkau aku ceraikan",atau dengan bahasa sindiran dan suami meniatkan perceraian, misalnya suami berkata kepada isterinya, "pergilah kepada keluargamu".5

\footnotetext{
${ }^{4}$ Al-Jazairi, Abu Bakr Jabir. 2003 Ensiklopedi Muslim. PT. Darul Fallah. Jakarta

${ }^{5}$ Al-Jazairi, Abu Bakr Jabir. 2003 Ensiklopedi Muslim. PT. Darul Fallah. Jakarta
} 
Dari Ibnu Umar R.A., beliau berkata; bersabda Rasulullah SAW; perbuatan halal yang paling dibenci Allah adalah talaq (H.R. Abu Daud dan Ibn Majah, dinilai shahih oleh al-Hakim, Abu Hatim menguatkan mursalnya). Hadits di atas secara tidak langsung menjelaskan bahwa dalam perbuatan yang halal itu terdapat beberapa perbuatan yang dimurkai oleh Allah SWT dan sesungguhnya perbuatan yang paling dimurkai oleh Allah SWT itu adalah talak. Kata "dibenci" adalah perkataan berbentuk majaz yang maksudnya: tidak mendapat pahala, tidak ada pendekatan diri kepada Allah SWT dalam perbuatan itu. Hadits ini mengandung makna sebaiknya menghindari perbuatan talak selama masih ada jalan keluarnya.

Talak diperbolehkan untuk menghilangkan madzarat dari salah satu dari suami-istri, karena Allah Ta'ala berfirman, "Talak (yang dapat dirujuki) dua kali, setelah itu boleh rujuk lagi dengan cara yang ma'ruf atau menceraikan dengan cara yang baik". (Al-Baqarah:229). Allah Ta'ala juga berfirman "Hai nabi, apabila kamu menceraikan isteri-isterimu maka hendaklah kamu ceraikan mereka pada waktu mereka dapat (menghadapi) iddahnya (yang wajar)".(Ath-Thalaq:1). ${ }^{6}$

Bisa jadi talak itu hukumnya wajib jika madzarat yang menimpa salah satu dari suami istri tidak bisa dihilangkan kecuali dengan talak, karena Rasullulah SAW bersabda kepada orang yang mengeluh kepada beliau tentang kebejatan isterinya, “ ceraikan dia”. (Diriwayatkan Abu Daud. Hadits shahih).7

Masalah kehidupan berrumah-tangga termasuk sesuatu yang mendapatkan perhatian serius dari AlQur-an. Dari hal siapa-siapa yang boleh dinikahi dan siapa yang tidak boleh dibicarakan sangat rinci oleh Al-Qur-an. Demikian jika jika harus terjadi perceraian, Al-Qur-an secara detail mengatur tentang langkahlangkah yang harus dilakukan oleh suami dan istri sewaktu terjadi ketidakharmonisan dalam rumah tangga. ${ }^{8}$

1. Sewaktu istri nuzuz, diatur oleh Allah pada Surat al-Nisä' (4): 34;

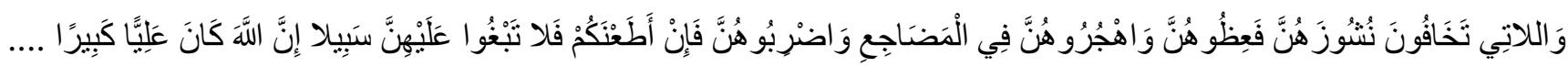

Artinya: "Dan terhadap wanita-wanita yang kamu khawatirkan nusyuznya,maka nasehatilah mereka dan pisahkanlah mereka di tempat tidurmu, dan pukullah mereka. kemudian jika mereka mentaatimu, maka janganlah kamu mencari-cari jalan untuk menyusahkannya, sesungguhnya Allah Maha Tinggi lagi Maha besar".

2. Ketika keadaan suami istri nampak adanya perselisihan yang tajam, Allah mengaturnya dalam surat AnNisa 35;

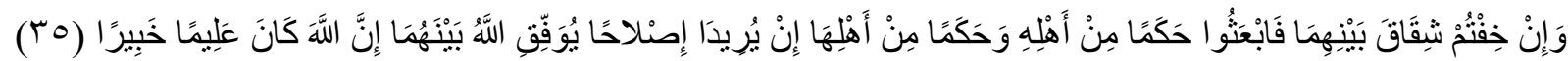
Artinya: "Dan jika kamu khawatirkan ada persengketaan antara keduanya, maka kirimlah seorang hakam dari keluarga laki-laki dan seorang hakam dari keluarga perempuan. jika kedua orang hakam itu bermaksud mengadakan perbaikan, niscaya Allah memberi taufik kepada suami-isteri itu, sesungguhnya Allah Maha mengetahui lagi Maha Mengenal.

3. Jika seorang istri menghadapi saminya telah menyimpang dari kewajiban-kewajibannya (nuzuz) sebagai seorang suami, Allah mengajarkannya dalam surat An-Nisa' ayat 128:

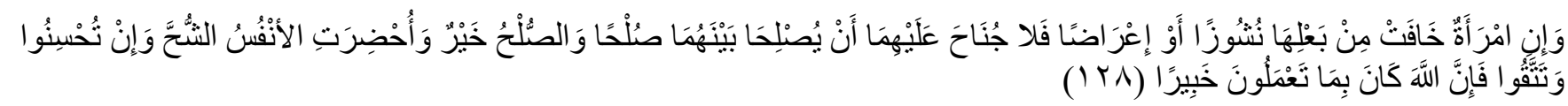

Artinya : "Dan jika seorang wanita khawatir akan nusyuz atau sikap acuh dari suaminya, maka tidak mengapa bagi keduanya mengadakan perdamaian yang sebenar-benarnya, dan perdamaian itu lebih baik (bagi mereka) walaupun manusia itu menurut tabiatnya kikir. dan jika kamu bergaul dengan

\footnotetext{
${ }^{6}$ Ibid

${ }^{7}$ Ibid

${ }^{8}$ Abd. Salam. Ikrar Talak Harus di Depan Sidang Pengadilan (Kajian Atas Pasal 39 UU Nomor 1/1974 Perspektif Ushul Fiqh).

http://www.pamataram.go.id/index.php?option= m_content\&view=article \&id=431:ikrar-talak-harus-di-depansidangpengadilan\&catid=37:artikel\&Itemid=87, diakses 1 November 2017 pukul 15.59
} 
isterimu secara baik dan memelihara dirimu (dari nusyuz dan sikap acuh), maka sesungguhnya Allah adalah Maha Mengetahui apa yang kamu kerjakan.

suami-istri benar telah merasakan bahwa rumah-tangga sudah tidak ada harapan untuk rukun dalam rumah tangga dan merasakan perceraian harus terjadi,

Allah mengaturNya dalam surat Ath-Thalaq ayat (1 dan 2);

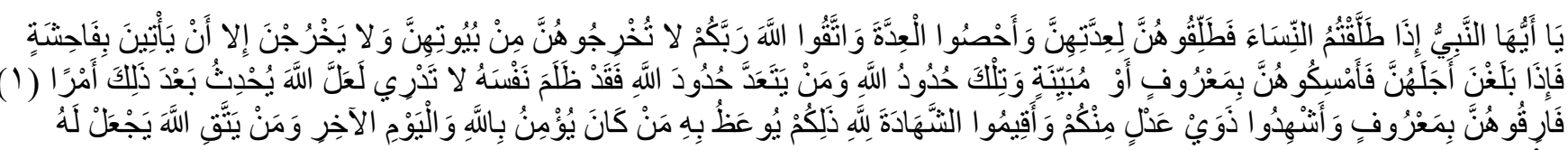

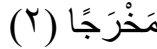

Artinya: "Hai Nabi, apabila kamu menceraikan isteri-isterimu, maka hendaklah kamu ceraikan mereka pada waktu mereka menghadapi iddahnya dan hitunglah waktu iddah itu serta bertakwalah kepada Allah Tuhanmu, janganlah kamu keluarkan mereka dari rumah mereka dan janganlah mereka kau izinkan mereka ke luar kecuali mereka mengerjakan perbuatan keji yang terang. Itulah hukum-hukum Allah, barang siapa melanggar ketentuan Allah maka sesungguhnya dia telah berbuat zalim terhadap dirinya sendiri. kamu tidak mengetahui barangkali Allah mengadakan sesudah itu sesuatu hal yang baru”.

"Apabila mereka telah mendekati akhir iddahnya, maka rujukilah mereka dengan baik atau lepaskanlah mereka dengan baik dan persaksikanlah dengan dua orang saksi yang adil di antara kamu dan hendaklah kamu tegakkan kesaksian itu karena Allah. demikianlah diberi pengajaran dengan itu orang yang beriman kepada Allah dan hari akhirat. barangsiapa bertakwa kepada Allah niscaya Dia akan mengadakan baginya jalan keluar.

Kiranya masih banyak lagi ketentuan-ketentuan Allah yang berkaitan dengan pembinaan keluarga.Dalam hal harus terjadi perceraian, Al-Qur-an menerangkan hal-hal yang berkaitan sebagai akibat hukum perceraian, antara lain: ${ }^{9}$

a. Suami berkewajiban memberi nafkah iddah;

b. Suami berkewajiban memberi muth'ah;

c. Suami dilarang mengambil kembali harta benda yang telah diberikan kepada istrinya yang ditalak.

Dari penjelasan di atas terlihat bagaimana agama islam dimana tertuang di dalam kitab suci Al-Qur'an mengatur secara jelas mengenai masalah keluarga.

Selain itu, terdapat hadits yang mengatur mengenai talak yang masih menjadi perdebatan, yaitu: Dari Abi Hurairah,sesungguhnya Rasulullah saw. bersabda:"Ada tiga perkara yang hukumnya samaantara sengaja dan tidak sengaja, yaitunikah, talak dan rujuk (HR. Abu Dawud). Hadis tersebut menurut Ibn 'Adī adalah ḍa'īf (lemah).Demikian juga menurut Ḥāris̉ ibn Abī Usāmah melalui hadis 'Ubādah ibn alṢāmityang telah menjadikan hadis itupada tingkat marfū' adalah ḍa 'īf dalamsanadnya, karena terdapat nama Ibn Luhai'ah dan hadis itu juga terjadi inqițā'(terputus sanadnya). (al-San 'ānī, t.th.: Juz II, 175-176) Akibatnya, jika mendasarkanpada hadis ini, putusnya perkawinanmelalui talak ini mudah sekali. Bahkan,kebanyakan mereka tidak memperhatikanhal-hal yang terjadi setelah talak, sepertinafkah, 'iddah, mut'ah, dan pemeliharaananak. Begitu juga, ayat al-Qur'an yangmengatur tahapan-tahapan jika suamiingin menceraikan istrinya, yaitu istrinusyūz (ketidakharmonisan), termaktubdalam QS al-Nisā'/4: 34, 35 dan suami nusyūz, termaktub dalam QS al-Nisā'/4:128. Suami tidak boleh langsungmenceraikan istrinya, tanpa melalui tahapan-tahapan, harus mempunyai alasan-alasan, apalagi yang nusyuz berasal dari suami. ${ }^{10}$

4. Perbedaan Pemahaman Konsep Ikrar Talak Menurut Putusan Pengadilan Agama dengan Syariat Islam

Penulis memberikan perbandingan konsep ikrar talak menurut putusan pengadilan Agama dengan syariat islam adalah sebagai berikut:

a. Jatuhnya Talak

\footnotetext{
${ }^{9}$ Ibid

${ }^{10}$ Abustam.2016.Pelaksanaan Ikrar Talak di Hadapan Sidang Pengadilan Agama (Suatu Tinjauan Filsafat Hukum Islam). Jurnal Hukum Keluarga Islam. Vol. II. No.2.159-178.Hal. 160
} 
Abdul Aziz Dahlan et.al dalam buku Ensiklopedi Hukum Islam menjelaskan bahwa talak dalambahasa arab artinya melepaskan dan meninggalkan suatu ikatan. Dalam istilah hukum talak adalah perceraian .......antara suami isteri atas kehendak suami . Sayyid Sabiq dalam Fiqh as Sunnah memberi definisi bahwa talak dalamterminology bahasaadalah " al-irsalu wa al-taraku" artinya melepaskan dan meninggalkan. Sedangkan menurutistilah hukum talak adalah " hillu rabithatin al zuwaj " artinya melepaskan ( ikatan ) taliperkawinan. Ulama fikih ( fukaha) berpendapat bahwa talak dibagi kepada dua macam yaitu :

1) Talak sunni, adalah talak yang dijatuhkan suami sesuai dengan petunjuk yang disyariatkan Islam, yaitu :

a) Menalak isteri harus secara bertahap ( dimulai dengan talak satu, dua dan tiga ) dan diselingirujuk.

b) Isteri yang ditalak itu dalam keadaan suci dan belum digauli dan

c) Isteri tersebut telah nyata-nyata dalam keadaan hamil.

2) Talak bid'i adalah talak yang dijatuhkan suami melalui cara-cara yang tidak diakui syariat islam yaitu:

a) Menalak isteri dengan tiga kali talak sekaligus,

b) Menalak isteri dalam keadaan haidh,

c) Menalak isteri dalam keadaan nifas, dan

d) Menjatuhkan talak isteri dalam keadaan suci tetapi telah digauli sebelumnya, padahalkehamilannya belum jelas.

Ulama fikih juga sepakat menyatakan bahwa menjatuhkan talak bid'i hukumnya haram danpelakunya mendapat dosa. Akan tetapi apabila terjadi juga seperti tersebut di atas, maka jumhur mengatakan talaknya tetap jatuh. Alasan mereka adalah talak bid'I itupun termasuk dalam keumuman ayat-ayat yang berbicara tentang talak, seperti surah al- Baqarah ayat 229-230, atTalak ayat 1-2, dan hadits Nabi SAW dalam kasus Abdullah bin Umar yang menjatuhkan talak terhadap isterinya yang sedang haid. Rasulullah bersabda "Suruh dia kembali pada isterinya sampai ia suci, kemudian suci, lalu suci lagi setelah itu jika ia ingin menceraikan isterinya itu, jika ingin menalak juga lakukanlah ketika itu (ketika suci belum digauli ( H.R. Muslim, AbuDawud, Ibnu Majash dan an Nasa'i ). ${ }^{11}$

Di dalam hukum yang berlaku di Indonesia yang mengatur tentang perkawinan, tidak diatur dan tidak dikenal pengertian talak di bawah tangan. Pengertian talak menurut Pasal 117 KHI adalah ikrar suami di hadapan sidang Pengadilan Agama yang menjadi salah satu sebab putusnya perkawinan Pasal 117 KHI menyatakan : "talak adalah ikrar suami di hadapan sidang Pengadilan Agama yang menjadi salah satu sebab putusnya perkawinan, dengan cara sebagaimana dimaksud dalam Pasal 129, 130, dan 131.

Melihat arti talak menurut syariat islam atau fiqih dan peraturan perundang-undangan terlihat perbedaan bahwa dalam syariat islam talak jatuh seketika suami mengucapkan talak ke pada istri pada waktu dan tempat yang tidak tertentu sementara menurut peraturan perundang-undangan, jatuhnya talak dimulai dengan adanya ikrar talak suami di hadapan sidang Pengadilan Agama tentunya setelah melalui proses-proses sesuai ketentuan beracara di Pengadilan Agama.

b. Upaya hukum

Di dalam syariat islam setelah adanya talak tidak ada upaya hukum lainnya. Tetapi, dalam syariat islam dikenal dengan rujuk. Rujuk dalam bahasa Arab berarti kembali artinya hidup sebagai suami isteri antara laki-laki dan wanita yang melakukan perceraian dengan jalan talak raj'iselama dalam masa iddahtanpa pernikahan baru. Akan tetapi jika masa iddahnya telah habis (talak raj'i), suami berniat untuk kembali, maka ia harus mulai dengan akad yang baru serta dengan mahar yang baru. Sedangkan pada kasus talak ba'in kubra, maka syarat untuk kembalinya suami kepada isterinya adalah, mantan isterinya menikah dahulu dengan lelaki lain, dan mereka melakukan

\footnotetext{
${ }^{11}$ Mahruddin Andry.2010.Persinggungan Fikih Dengan Pasal 39 Undang-Undang Nomor 1 Tahun 1974 Tentang Perkawinan dan Pasal 34 Peraturan Pemerintah Nomor 9 Tahun 1975 dalam Masalah Talak di Bawah Tangan. http://www.ptamedan.go.id/attachments/076_PERSINGGUNGAN\%20FIKIH.pdf, diakses1 November 2017 pukul 17.11
} 
hubungan suami-isteri dan setelah itu suaminya menceraikannya. Setelah berakhirnya masa iddah, barulah suaminya yang pertama boleh menikahinya dengan akad baru.

Dalam perkembangan selanjutnya, tata cara rujuk tidaklah sesederhana yang digambarkan oleh ulama fikih. Pengertian rujuk ini juga diisyaratkan dalam pasal 163KHI yaitu: seorang suami dapat merujuk isterinya yang dalam masa iddah.Tata cara rujuk berikut tata caranya diatur dalam KHI.

Berbeda dengan syariat islam, penerapan acara hukum perdata menyebabkan adanya upaya hukum banding dan kasasi kepada suami yang mengajukan gugat talak. Hal tersebut tidak sesuai dengan syariat islam karena hak talak ada di suami seharusnya tidak mungkin ada suami yang mengajukan permohonan talak kemudian ditolak permohonannya.

Di dalam syariat islam, Talak yang ada di tangan suami itu merupakan keadilan, karena suamilah yang memegang ikatan akad nikah, maka dialah yang wajib menguraikan ikatan itu, dan karena suami pula lah yang memimpin dan mengurusi istri, sebagaimana firman Allah Subhannahu wa Ta'ala ,"Kaum laki-laki itu adalah pemimpin bagi kaum wanita, oleh karena Allah telah melebihkan sebagian mereka (laki-laki) atas sebagian yang lain (wanita)." (An-Nisa: 34). ${ }^{12}$

c. Berlakunya masa iddah

Iddah ialah hari-hari dimana wanita yang ditalak menjalani masa penantian. Pada masa-masa tersebut, ia tidak boleh menikah dan tidak boleh meminta dinikahi. ${ }^{13}$

Menurut Sayitu Thalib, pengertian kata iddah dapat dilihat dari dua sudut pandang: ${ }^{14}$

1) Dilihat dari segi kemungkinan keutuhan perkawinan yang telah ada, suami dapat rujuk kepada isterinya. Dengan demikian maka kata iddah dimaksudkan sebagai suatu istilah hukum yang mempunyai arti tenggang waktu sesudah jatuh talak, dalam waktu mana pihak suami dapat merujuk kepada istrinya.

2) Dengan demikian dilihat dari segi isteri, maka masa 'iddah itu akan berarti sebagai suatu tenggang waktu dalam waktu mana isteri belum dapat melakukan perkawinan dengan pihak laki-laki lain.

Adapun hikmah disyari'atkannya 'iddah adalah sebagai berikut:

1) Mengetahui terbebasnya rahim, dan sehingga tidak bersatu air mani dari dua laki-laki atau lebih yang telah menggauli wanita tersebut pada rahimnya. Sehingga nasab anak yang mungkin dilahirkan tidak menjadi kacau.

2) Menunjukkan keagungan, kemulian masalah pernikahan dan hubungan badan.

3) Memberi kesempatan bagi sang suami yang telah mentalak istrinya untuk rujuk kembali. Karena bisa jadi ada suami yang menyesal setelah mentalak istrinya.

4) Memuliakan kedudukan sang suami di mata sang istri. Sehingga dengan adanya masa iddah akan semakin menampakkan pengaruh perpisahan antara pasangan suami-istri. Karena itu, di masa iddah karena ditinggal mati, wanita dilarang untuk berhias dan mempercantik diri, sebagai bentuk berkabung atas meninggalkan sang kekasih.

5) Berhati-hati dalam menjaga hak suami, kemaslahatan istri dan hak anak-anak, serta melaksanakan hak Allah yang telah mewajibkannya. [Lihat I'laamul Muwaqqi'iin (II/85)]

Masa 'iddah setiap wanita dapat berbeda-beda, berdasarkan keadaannya dan sebab perpisahannya. Berikut beberapa rinciannya: ${ }^{15}$

1) Wanita yang ditinggal mati suaminya, baik dia sudah dicampuri ataupun belum, maka masa 'iddahnya adalah 4 bulan 10 hari. Sebagaimana disebutkan dalam firman Allah Ta'ala,

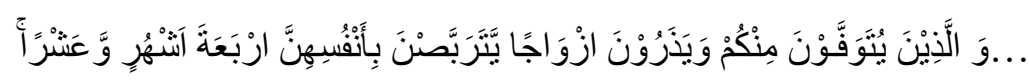

12 Al sofwa. 2004. Hikmah Kenapa Hak Talak Itu Ada Pada Suami. Hukum Talak Tanpa Sebab (alas an). http://www.alsofwa.com/4553/681-fatwa-hikmah-kenapa-hak-talak-itu-ada-pada-suami-hukum-talak-tanpa-sebab-alas-an.html, diakses 1 November 2017 pukul 21.02

${ }^{13}$ Al-Jazairi, Abu Bakr Jabir, Op.Cit., hal.612

${ }^{14}$ Nuruddin, Amir, Azhari Akmal Tarigan. 2004. Hukum Perdata Islam di Indonesia (Studi Kritis Perkembangan Hukum Islam dari Fikih, UU No. 1 Tahun 1974 sampai KHI), Prenada Media. Jakarta

${ }^{15}$ Ummu Sa'id. 2011. Talak Bagian 8 ('iddah) https://muslimah.or.id/1809-talak-bagian-8-iddah.html, diakses pada 1 November 2017 Pukul 22.40 
"Orang-orang yang meninggal dunia di antaramu dengan meninggalkan istri-istri (hendaklah para istri itu) menangguhkan dirinya (ber'iddah selama) empat bulan sepuluh hari." (Qs. Al-Baqarah: 234)

2) Wanita yang ditalak dan sudah dicampuri suami, serta masih dalam usia haid maka masa 'iddahnya adalah selama tiga kali haid. Setelah masuk masa suci yang ketiga maka masa 'iddahnya telah habis. Hal ini berdasarkan firman Allah Ta'ala,

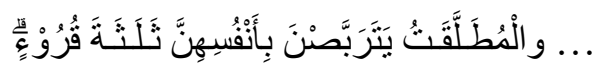

"Wanita-wanita yang ditalak hendaklah menahan diri (menunggu) tiga kali quru'." (Qs. AlBaqarah: 228). Dan lafazh quru' (عورق) pada ayat di atas maknanya adalah haidh. [Lihat penjelasan mengenai hal ini dalam Terj. Subulus Salam (III/126-132) dan kitab lainnya]

3) Wanita yang ditalak dan tidak mengalami haid, misalnya karena masih kecil atau sudah tua (menopause), maka masa 'iddahnya adalah 3 bulan. Allah berfirman :

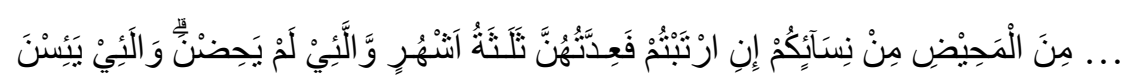

"Wanita-wanita yang tidak haidh lagi (menopause) di antara istri-istrimu jika kamu ragu-ragu (tentang masa 'iddahnya), maka 'iddahnya adalah tiga bulan. Dan begitu (pula) perempuanperempuan yang tidak haidh.” (Qs. Ath-Thalaaq: 4)

4) Wanita yang ditalak oleh suaminya dan belum dicampuri, maka tidak ada iddah baginya. Sebagaimana disebutkan dalam firman Allah Ta'ala,

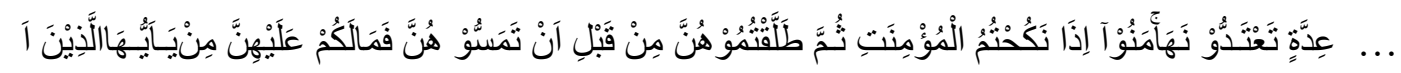

"Wahai orang-orang yang beriman, apabila kamu menikahi wanita-wanita mukmin, kemudian kamu ceraikan mereka sebelum kamu mencampurinya maka tidak ada masa 'iddah atas mereka yang perlu kamu perhitungkan.." (Qs. Al-Ahzaab: 49)

5) Wanita yang ditalak atau ditinggal mati oleh suaminya dalam keadaan hamil, maka masa 'iddahnya adalah sampai melahirkan. Hal ini berdasarkan firman Allah Ta'ala,

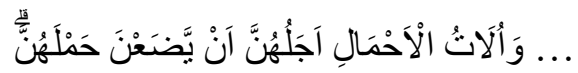

"Dan wanita-wanita yang hamil, (waktu iddah mereka itu) adalah sampai mereka melahirkan kandungannya." (Qs. Ath-Thalaq: 4)

6) Wanita al-Murtaabah. Wanita murtabah adalah wanita yang siklus haidnya tidak teratur. Wanita dalam kondisi ini ada dua keadaan:

a) Sebelumnya memiliki siklus haid yang teratur kemudian siklus haidnya berubah karena sebab yang diketahui, seperti menyusui, cacat atau sakit yang masih ada harapan untuk sembuh. Dalam kondisi ini, wanita diwajibkan untuk bersabar sampai siklus haidnya kembali normal, meskipun waktunya panjang. Setelah siklus haid kembali normal maka dia menjalani masa iddahnya dengan hitungan quru' (menjalani 3 kali haid). Ini adalah pendapat Utsman bin Affan, Ali bin Abi Thalib, dan Zaid bin Tsabit radhiyallahu 'anhum.

b) Sebelumnya memiliki siklus haid yang teratur kemudian siklus haidnya berubah namun sebabnya tidak diketahui. Dalam kondisi ini, wanita wajib menunggu selama 9 bulan, sehingga diketahui dengan pasti bahwa rahimnya bersih, kemudian melakukan 'iddahnya selama 3 bulan. Dengan demikian, 'iddahnya menjadi 1 tahun. [Lihat Ad-Dasuqi (II/470), Al-Mughni (VII/466), dan Ensiklopedi Fiqh Wanita (II/420-421), Mausu'ah Fiqhiyah Kuwaitiyah (XXIX/329)]Hal ini berdasarkan perkataan 'Umar bin Al-Khaththab radhiyallahu 'anhu, tentang wanita murtabah namun sebabnya tidak diketahui, "Hendaklah ia menunggu selama sembilan bulan, kemudian jika tidak nampak pada dirinya (tanda-tanda) kehamilan, maka hendaklah ia melakukan 'iddah 
selama tiga bulan, maka semuanya menjadi satu tahun penuh." [Riwayat Imam Asy-Syafi'i dalam Musnadnya (II/107 Syifaa-ul 'Ayy)]

c) Wanita al-mustahadhah. Dalam kondisi istihadhah, wanita ada dua keadaan:

(1) Dia dapat membedakan antara darah haidh dan darah istihadhah, maka 'iddahnya adalah tiga kali siklus haid.

(2) Dia tidak dapat membedakan antara darah haidh dan darah istihadhah. Wanita yang mengalami kondisi semacam ini disebut al-mutahayyirah (wanita yang ragu), dan masa 'iddahnya adalah selama 3 bulan. [Lihat Fat-hul Baari (IV/312), Ad-Dasuqi (II/470), Mughni Muhtaaj (III/385), Al-Mughni (III/468), dan Ensiklopedi Fiqh Wanita (II/ 421)]

Hal ini berdasarkan keumuman firman Allah Ta'ala,

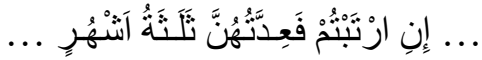

“...jika kamu ragu-ragu (tentang masa 'iddahnya), maka 'iddahnya adalah tiga bulan..." (Qs. Ath-Thalaaq: 4)

Mengenai masa iddah atau masa tunggu dalam hal terjadi perceraian,diatur juga dalam peraturan hukum di Indonesia. Dapat dilihat jangka waktunya dalam Pasal 153 ayat (2) KHI yang berbunyi "Waktu tunggu bagi seorang janda ditentukan sebagai berikut :

a. Apabila perkawinan putus karena kematian, walaupun qabla al dukhul, waktu tunggu ditetapkan 130 (seratus tiga puluh) hari.

b. Apabila perkawinan putus karena perceraian waktu tunggu bagi yang masih haid ditetapkan 3 (tiga) kali suci dengan sekurang-kurangnya 90 (sembilan puluh) hari, dan bagi yang tidak haid ditetapkan 90 (sembilan puluh) hari.

c. Apabila perkawinan putus karena perceraian sedang janda tersebut dalam keadaan hamil, waktu tunggu ditetapkan sampai melahirkan.

d. Apabila perkawinan putus karena kematian, sedang janda tersebut dalam keadaan hamil, waktu tunggu ditetapkan sampai melahirkan.

Kaitannya dengan masa iddah, yang menjadi permasalahan adalah penentuan mulainya masa iddah. Dalam fiqh/syariat islam penentuan awal masa iddahtergantung pada kondisi wanita saat perceraian terjadi dalam keadaan suci sedang haid, sudah dikumpuli dalam masa suci atau tidak berhaid. Pada wanita berhaid yang bercerai dalam keadaan suci dan belum berkumpul pada masa suci iddahnya dimulai sejak masa suci saat terjadinya perceraian. Pada wanitaberhaid yang bercerai dalam keadaan haid atau telah berkumpul pada masa suci saat bercerai iddahnya mulai dihitung pada masa suci setelahnya. Dan pada wanita yang tidak berhaid, iddahnya dihitung sejak hari jatuhnya talak.

Dalam KHI iddahdihitung sejak penetapanperceraian yang mempunyai kekuatan hukum tetap. Penetapan berkekuatan hukum tetap apabila tidak ada upaya hukum dari tergugat selama batas waktu pengajuan upaya hukum. Apabila ada upaya hukum, maka iddahdihitung sejak penetapan upaya hukumtelah berkekuatan hukum tetap.

\section{SIMPULAN}

Perbandingan konsep ikrar talak menurut putusan pengadilan Agama dengan syariat islam adalah sebagai berikut:

a. Jatuhnya talak

Talak dalam syariat islam talak jatuh seketika suami mengucapkan talak ke pada istri pada waktu dan tempat yang tidak tertentu sementara menurut peraturan perundang-undangan, jatuhnya talak dimulai dengan adanya ikrar talak suami di hadapan sidang Pengadilan Agama tentunya setelah melalui prosesproses sesuai ketentuan beracara di Pengadilan Agama.

b. Upaya hukum

Dalam syariat islam setelah adanya talak tidak ada upaya hukum tetapi dikenal adanya rujuk saja. Sedangkan menurut peraturan perundang-undangan terdapat upaya hukum banding dan kasasi.

c. Berlakunya masa iddah 
Dalam KHI iddah dihitung sejak penetapan perceraian yang mempunyai kekuatan hukum tetap. Sementara menurut syariat islam tergantung pada kondisi wanita pada saat jatuhnya talak.

\section{DAFTAR PUSTAKA}

Al-Jazairi, Abu Bakr Jabir. 2003 Ensiklopedi Muslim. PT. Darul Fallah. Jakarta

Nuruddin, Amir, Azhari Akmal Tarigan. 2004. Hukum Perdata Islam di Indonesia (Studi Kritis Perkembangan Hukum Islam dari Fikih, UU No. 1 Tahun 1974 sampai KHI), Prenada Media. Jakarta

Abustam. Pelaksanaan Ikrar Talak di Hadapan Sidang Pengadilan Agama (Suatu Tinjauan Filsafat Hukum Islam). Jurnal Hukum Keluarga Islam, Vol. II, No.2,Hal. 159-178

Azzam, A.A.M., Hawwas,A.W.S. 2009. Fiqh Munakahat, AMZAH, Jakarta

Ismatulloh, A.M. 2015. Konsep Sakinah, Mawaddah dan Rahmah dalam Al-Qur'an (Prespektif Penafsiran Kitab Al Qur'an dan Tafsirnya),Jurnal Mazahib. Vol. XIV. No. 1, Hal. 53-63

Abd. Salam. Ikrar Talak Harus di Depan Sidang Pengadilan (Kajian Atas Pasal 39 UU Nomor 1/1974 Perspektif Ushul Fiqh).

http://www.pamataram.go.id/index.php?option=m_content\&view=article\&id=431:ikrar-talak-harus-didepan sidangpengadilan\&catid=37:artikel\&Itemid $=87$

Al sofwa. 2004. Hikmah Kenapa Hak Talak Itu Ada Pada Suami. Hukum Talak Tanpa Sebab (alasan). http://www.alsofwa.com/4553/681-fatwa-hikmah-kenapa-hak-talak-itu-ada-pada-suami-hukum-talaktanpa-sebab-alas-an.html

Ummu Sa'id. 2011. Talak Bagian 8 ('iddah) https://muslimah.or.id/1809-talak-bagian-8-iddah.html

Mahruddin Andry.2010.Persinggungan Fikih Dengan Pasal 39 Undang-Undang Nomor 1 Tahun 1974 Tentang Perkawinan dan Pasal 34 Peraturan Pemerintah Nomor 9 Tahun 1975 dalam Masalah Talak di Bawah Tangan. http://www.pta-medan.go.id/attachments/076_PERSINGGUNGAN\%20FIKIH.pdf 